\title{
A erotização do imaginário do pop-rock brasileiro nas canções de Rita Lee
}

\begin{abstract}
SÍLVIO A. L. ANAZ*
RESUMO: Este artigo analisa o processo de construção de um imaginário de amor romântico erotizado na canção popular a partir de alguns dos principais sucessos compostos por Rita Lee. Para compreender o processo de criação desse imaginário, a investigação parte dos diálogos que a artista estabeleceu com a cultura, nos anos de sua formação e na época de composição das obras aqui analisadas, e avança até a semiose de suas letras e músicas. A análise do processo de formação de imaginários fundamenta-se no conceito de imaginário, desenvolvido por Gilbet Durand, na ideia de neotribalização, elaborada por Michel Maffesoli, e na análise textual de Roland Barthes. A conclusão mostra o arquétipo da protagonista feminina com pretensões libertárias e altamente sexualizada como elemento central do percurso entre a rede de diálogos estabelecidos pela artista com a cultura e os elementos simbólicos presentes no imaginário das suas canções.
\end{abstract}

PALAVRAS-CHAVE: canção; imaginário; processo criativo; semiótica; cultura midiática

\section{The eroticization of Brazilian pop-rock imaginary by Rita Lee songs}

\begin{abstract}
This paper analyses the process of building an erotic romantic love imaginary, based on Rita Lee songs. With the purpose of understanding the process of construction of an imaginary, this research investigates songwriter's dialogues with local and international cultures and the semiosis of songs. The analysis uses the concept of imaginary, developed by Gilbert Durand, the idea of urban tribes, developed by Michel Maffesoli, and the Roland Barthes textual analysis methodology. The conclusion shows the archetype of a libertarian female protagonist, highly eroticized, as a central element in the trajectory that comes from songwriter's cultural dialogues to symbolic elements present in the songs imaginary.
\end{abstract}

KEYWORDS: Song; imaginary; creative process; semiotics; media culture

\footnotetext{
* Sílvio A. L. Anaz é Doutorando em Comunicação e Semiótica na Pontifícia Universidade Católica de São Paulo. Formado em Comunicação Social pela Universidade de São Paulo, com Mestrado em Letras pela Universidade Presbiteriana Mackenzie. E-mail: silvioanaz@hotmail.com. 


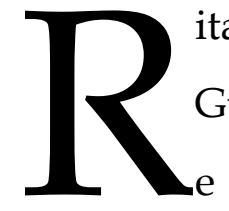

ita Lee considerava, na segunda metade da década de 1960, o rock da Jovem Guarda ingênuo demais, principalmente quando comparado ao que artistas grupos internacionais, especialmente os britânicos, estavam fazendo naquele momento. Nas turmas pelas quais transitava nos tempos de ginásio no Liceu Pasteur, em São Paulo, uma sexualidade muito mais atrevida do que a cantada nas canções jovem-guardistas já era uma questão muito presente no seu cotidiano.

Foi nessa época, que ela descobriu o rock, ao ouvir "Hound Dog", de Elvis Presley, e ficar contaminada pela energia do gênero. A associação entre a sensualidade e rebeldia de Elvis com a de outro de seus ídolos juvenis, James Dean, definiu sua vocação para a música e sua adesão à tribo urbana do rock (BARTSCH, 2006, p. 38), o que lhe rendeu seus primeiros desafios sociais e artísticos: "Sempre fui persona non grata na escola. Quando comecei na música, diziam que eu era uma gringa riquinha fazendo rock imperialista" (LEE, 2007).

Nos anos seguintes, Rita se tornaria uma das protagonistas da renovação na canção popular brasileira ao integrar Os Mutantes. O grupo foi seminal no Tropicalismo, movimento que, assim como a Bossa Nova e a Jovem Guarda, propôs uma atualização da canção nacional a partir do sincretismo de elementos da cultura brasileira com a internacional. Após deixar Os Mutantes, a artista consolida-se ao longo dos anos 1970 como um dos principais nomes do pop-rock no país. Nessa trajetória, suas canções contribuíram na construção dos diversos imaginários que emergiram da canção popular. Este estudo parte da percepção de que uma dessas contribuições foi em relação à introdução de elementos simbólicos que elevaram o grau de erotismo no imaginário do amor romântico do pop-rock brasileiro.

O amor romântico é um dos temas mais presentes na canção popular¹. Entre as composições que ocuparam o primeiro lugar na parada de sucesso norte-americana, apurada pela Billboard entre 1956 e 2000, 70\% o tinham como tema central. Sua presença é notável também nas canções de sucesso no Brasil. Assim, desde os anos 1950, o pop-rock tem construído imaginários do amor romântico que foram disseminados e

\footnotetext{
${ }^{1}$ Estudo de Daniel Levitin mostra que o amor é uma das seis categorias da canção responsáveis pela construção e transmissão da natureza cultural humana. As outras são: amizade, contentamento, consolo, conhecimento e religião (LEVITIN, 2008). 
compartilhados pelos meios de comunicação e pelos produtos das indústrias criativas. O amor romântico é aqui entendido como uma crença emocional inventada historicamente pelo ser humano, em que "nenhum de seus constituintes afetivos, cognitivos ou conativos é fixo por natureza" (COSTA, 1988, p.12). Uma das partes essenciais que compõem a ideia e o imaginário do amor romântico diz respeito ao erotismo. Para o poeta e ensaísta mexicano Octavio Paz, “o fogo original e primordial, a sexualidade, levanta a chama vermelha do erotismo e esta, por sua vez, sustém e ergue outra chama azul e trêmula: a do amor" (PAZ, 1994, p. 7). Paz viu o amor como a "metáfora final da sexualidade", uma purificação que "transforma o sujeito e o objeto de encontro erótico em pessoas únicas" 2 (ibidem, p. 97).

Nesta investigação, busca-se mapear o imaginário do amor romântico que emerge de alguns dos principais sucessos de Rita Lee. A hipótese é de que há na sua obra a presença de elementos simbólicos que produzem uma erotização acentuada do amor romântico no pop-rock brasileiro da época, fruto de uma atualização de imagens femininas arquetípicas que emergiam com mais força naquele contexto social e histórico em que se inseria o trabalho de Rita Lee como compositora e intérprete.

Desde o começo de sua trajetória artística, Rita Lee não desejava apenas aderir às tribos que surgiram tendo o rock como centro gravitacional, mas sim ser um dos ícones e ajudar a construir o imaginário em torno dos quais essas tribos flutuavam. Ela se identificava com a atitude, a fantasia, o som, o visual, o sucesso, o discurso, o

\footnotetext{
2 A esse idealismo platônico de Paz contrapõem-se pensamentos que veem o amor romântico idealizado como um engodo e até mesmo como fonte de alienação. Apesar de díspares, as visões sobre o amor romântico revelam algumas características comuns dessa crença emocional e são justamente elas as que interessam neste estudo. É importante observar que o sujeito do amor romântico não é sempre o mesmo desde os tempos do Romantismo, o que faz com que o amor romântico também venha se transformando, pois, como uma crença emocional, ele é permanentemente reinventado pelo homem, em função dos contextos históricos, das condições sociais e econômicas e das transformações culturais. Apesar disso, há um núcleo de ideais e valores que tem atravessado os últimos três séculos e construído imaginários do amor romântico. Esses imaginários têm alimentado e têm sido alimentados pelas artes. Sem entrarmos no mérito se esses ideais e valores estão ou não contribuindo para a felicidade ou a infelicidade de quem neles acredita, se eles são excessivamente idealistas ou se viraram fetiches poderosos demais, há um conjunto de sensações e sentimentos que têm caracterizado o amor romântico. Assim, para fins desta investigação, consideramos o amor romântico uma crença emocional de envolvimento afetivo e/ou sexual, manifestada em índices do amor-paixão, como erotismo, sexo, infidelidade, angústia, carinho, ciúme, culpa, nostalgia, sedução, união, paixão à primeira vista, separação, solidão e provas de amor, entre outros.
} 
sentimento de pertencer a uma banda de rock e lhe seduzia a possibilidade de interpretar canções do gênero sobre o amor (BARTSCH, 2006, p. 51).

Nesse sentido, é importante compreender os diálogos com a cultura que a compositora estabeleceu ao longo de sua trajetória em um contexto de adesão a microgrupos sociais - denominados como "cenas", "subculturas" ou "tribos urbanas" - que se formaram em torno de determinadas estéticas da canção midiática. Trata-se, assim, de analisar um trajeto de construção de imaginários que parte dos diálogos culturais estabelecidos pela artista, em seus anos de formação e de composição das canções analisadas, e desemboca nas imagens e nos significados (semiose) predominantes nas letras e músicas que criou.

\section{Mediações culturais na trajetória de Rita Lee}

Os diálogos que o compositor da canção popular estabelece com a cultura ocorrem na cotidianidade, nos espaços e tempos em que a cultura se torna concreta, seja no cotidiano familiar, no trabalho, na escola e nas experiências estéticas do indivíduo, entre outros lugares e situações, como bem demonstra a ideia de mediações culturais de Martín-Barbero (2009).

Ao situar-se como um receptor e ao mesmo tempo um criador dos produtos da indústria cultural, o compositor de canções midiáticas estabelece em seu processo de fruição e criação negociações que são mediadas pelo contexto em que está inserido, pelas estruturas sociais ao seu redor e também por suas atitudes e percepções subjetivas das práticas comunicativas e culturais.

O compositor do pop-rock atua, assim, como um mediador cultural inserido em um contexto, a partir da segunda metade do século $X X$, em que o imaginário que emerge da canção midiática torna-se elemento central em um fenômeno que Michel Maffesoli denominou como "neotribalização" (tribos urbanas).

Isso evidencia-se no caso de Rita Lee ao se analisar seus depoimentos sobre sua trajetória artística, coletados em entrevistas e em sua biografia. Neles, a artista re- 
vela os elementos com os quais dialogou das culturas brasileira e internacionais e destaca, por exemplo, a influência dos ídolos cinematográficos e dos primeiros grandes astros do rock em seu trabalho:

[Meus ídolos] eram mais cinematográficos que musicais. Fred Astaire, Carmem Miranda, pelo visual dela exagerado. Claro, Elvis Presley na veia, Stones e Beatles na veia, Chuck Berry na veia para chuchu. Sou da época de quem assistiu Jimi Hendrix ao vivo duas vezes (LEE, 1997).

Entre a segunda metade dos anos 1960, quando foi uma das protagonistas do grupo Os Mutantes e do movimento tropicalista, e a primeira metade dos anos 1980, Rita Lee construiu uma carreira de sucessos que a levaram a ser considerada a "rainha do rock" brasileiro. Seus relatos mostram que nesse período, ela transitou predominantemente por grupos sociais que se constituíram em torno da música, especialmente ligados ao rock e à atualização da música brasileira, como no caso dos tropicalistas, e de movimentos libertários alternativos, como os hippies (BARTSCH, 2006).

No contexto social e histórico, em que se inseriram os diálogos culturais que Rita Lee estabeleceu, ocorre o auge do movimento feminista e de um pensamento libertário e, ao mesmo tempo, as restrições políticas e de liberdade de expressão e organização impostas pelo regime militar e ditatorial no Brasil. Essas eram algumas das forças que impactavam na produção cultural da época no país ${ }^{3}$.

A trajetória de vida e as inspirações das composições de Rita Lee trazem índices de como a ambiência dos grupos sociais pelos quais transitou refletiram na construção do imaginário do amor romântico em suas criações. Do "pioneirismo" no uso de minissaias, nos tempos de ginásio no Liceu Pasteur, até a adesão à sensualidade provocativa dos artistas tropicalistas (BARTSCH, 2006), as letras de suas composições incorporaram os temas e as imagens de relações amorosas em que o sexo esteve muito presente, de uma forma muito mais explícita e "carnal" do que o tratamento dado pela Jovem Guarda, por exemplo.

\footnotetext{
${ }^{3} \mathrm{Na}$ produção musical brasileira, o amor romântico ganhava diferentes leituras como as da Jovem Guarda, do Tropicalismo e da Bossa Nova, movimentos que buscavam uma atualização da canção nacional em relação ao panorama internacional, mas também as da MPB, como na sofisticação lírica das composições de Chico Buarque de Holanda, e as da chamada música brega, que surge na esteira da Jovem Guarda e avança pela década de 1970, caracterizada pelo sentimentalismo exagerado e dramático. 
A auto-percepção de sua trajetória artística mostra também que a construção do imaginário do amor romântico em suas canções se dá principalmente a partir da ambiência da Tropicália:

Gosto de uma boa salada mista com temperos variados, sou aluna exemplar do Tropicalismo.... Caetano é meu mestre há 30 anos. Sou uma discípula grata por ter aprendido com ele e Gil a fazer música (LEE, 2000).

A gente meio que ironizava porque a estética e o discurso musical do Tropicalismo diferiam bastante dos da Jovem Guarda. Hoje, com o distanciamento do tempo, percebo que ambos os movimentos foram do cacete. Mas, ainda assim, o visual tropicalista dava um pau no deles (ibid).

O Tropicalismo foi a semente mais genial que foi plantada na minha cabeça, viver aquilo de perto me ensinou a ser o que sou (LEE, 2008).

Contribui especialmente para a construção desse imaginário o processo de identificação cultural da artista com o rock e a atmosfera de libertação comportamental que o gênero inspirava. Da sua adolescência, quando as midiáticas "I Want to Hold Your Hand" (1964), “Love Me Do" (1962) e "She Loves You" (1963), dos Beatles, a contagiaram (BARTSCH, 2006, p. 51), à adesão às propostas de hibridização cultural da Tropicália, ela se percebe como uma artista capaz de romper com preconceitos culturais e defender a igualdade entre homens e mulheres:

Não nasci para casar e lavar cuecas. Queria a mesma liberdade dos moleques que brincavam na rua com carrinho de rolimã. Quando entrei para a música, percebi que a "tchurma" dos culhões reinava absoluta, ainda mais no rock. "Oba", dizia eu, "é aqui mesmo que vou soltar a franga e, literalmente, encher o saco deles". Depois que provei a mim mesma que era capaz de conseguir as mesmas vitórias, sosseguei um pouco o facho. Principalmente depois que Roberto entrou na minha vida feito um Lancelot. Minha Guinevere pôde então exercer a função de namorada, amante e mãe. No palco, sou mais macho do que fora dele, não posso negar que minhas influências como figura de frente foram Jagger, Bowie, Tyler, Rod Stewart. E no Brasil? Vou começar com Carmen Miranda, que me ensinou que uma gringa pode ser a mais brasileira de todas. Caetano e Gil me apresentaram ao Brasil brasileiro e me ensinaram como fazer música em português. Tom Zé me iniciou na patafísica. Paulo Coelho me ensinou a ler tarô e a pressentir uma inspiração (LEE, 2007).

Nas mediações que a compositora estabeleceu (figura 1) verifica-se que determinados gêneros da canção (Jovem Guarda, Tropicalismo, rockabilly, beat britânico, glam rock) ocuparam um significativo lugar: 


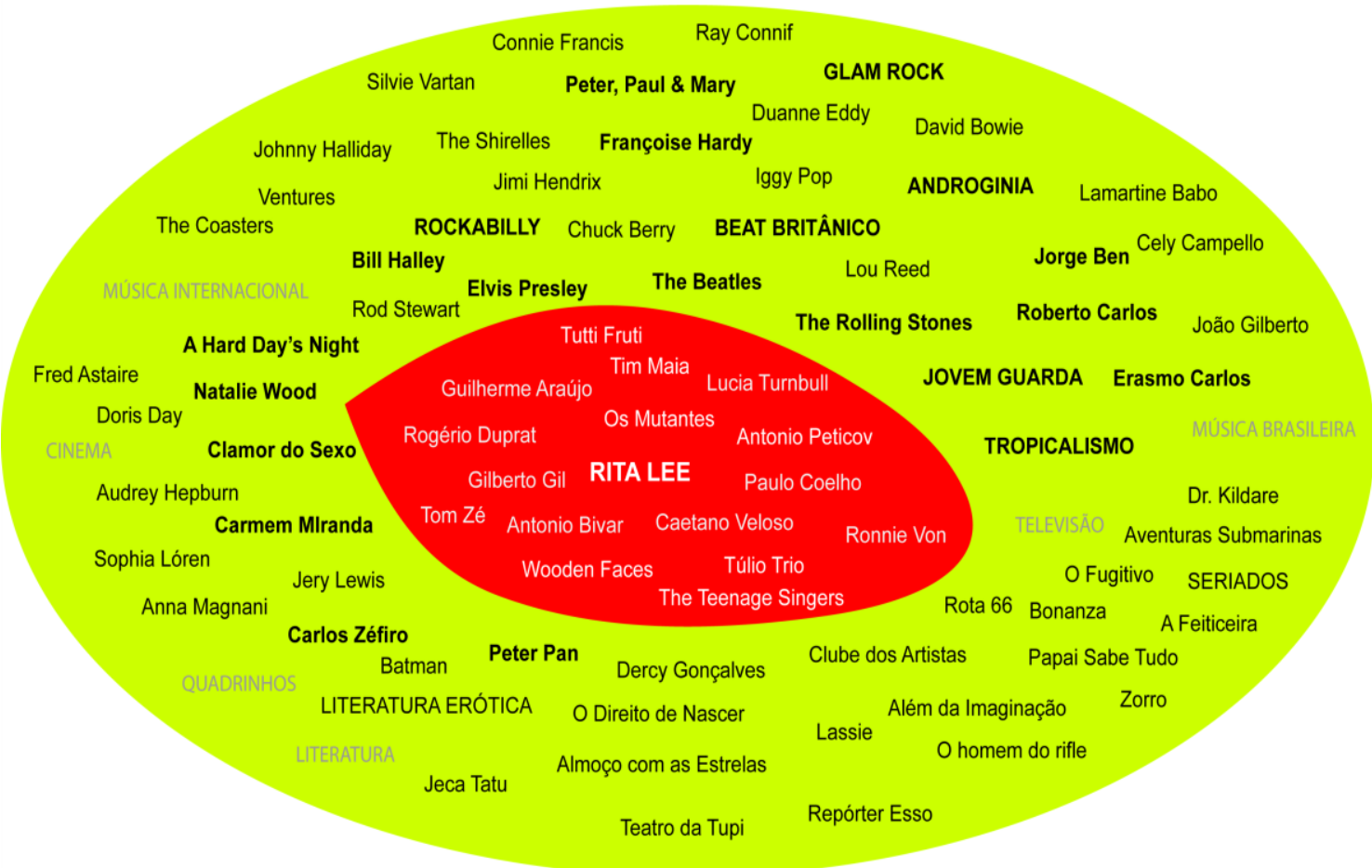

Figura 1: Mapa dos principais diálogos culturais estabelecidos por Rita Lee

Parte desses diálogos foram o resultado do transitar e da adesão da compositora a tribos urbanas que se formaram em torno de algumas das principais estéticas do pop-rock dos anos 1960 e 1970. Nesse sentido, o imaginário assume um papel central no processo de identificação e adesão do compositor e dos apreciadores das canções às estéticas, éticas e costumes de determinadas tribos urbanas.

\section{Imaginário como "cimento social"}

Michel Maffesoli (2010) entende que o imaginário extrapola o plano individual para se constituir no patrimônio de um grupo, em um patrimônio "tribal", constituído por sensações, lembranças, afetos e estilos de vida comuns. Maffesoli segue os passos de Gilbert Durand que definiu o imaginário como um processo antropológico, um processo de formação do arcabouço de imagens, símbolos, mitos e arquétipos, que o ser humano tem produzido (DURAND, 2002).

O imaginário surge, segundo Durand, da necessidade do homem de lidar com as angústias essenciais (consciência da morte e irreversibilidade do tempo) e de buscar um equilíbrio biopsicossocial. Para tanto, o ser humano desenvolve atitudes 
imaginativas que Durand (2002) agrupa em dois regimes de imagens: o Diurno, com atitudes que buscam negar e superar a morte e o tempo, resultando em imagens e estruturas heroicas; e o Noturno, com atitudes que transmutam e eufemizam a mortalidade e a mobilidade do tempo, resultando em imagens e estruturas místicas ou sintéticas (que reúnem o místico e o heroico). Durand estabelece uma relação entre essas estruturas e os reflexos biológicos básicos do ser humano (postural, copulativo e digestivo). O postural relaciona-se com as atitudes heroicas do Regime Diurno, que remetem aos movimentos de ascensão, de luta, de olhar para o céu e de iluminação. $O$ reflexo digestivo é associado ao Regime Noturno. Seus movimentos de descida e acocoramento remetem a um retorno uterino, um penetrar nas trevas e no que é escondido, calmo, quente, íntimo e profundo. O reflexo copulativo liga-se às estruturas sintéticas (ou dramáticas). O imaginário, nessa visão antropológica, constitui-se em uma via de mão dupla que liga o biológico ao social (cultural).

O que se entende por imaginário individual alimenta e é alimentado pelo imaginário coletivo de um grupo, de uma nação, de uma comunidade, funcionando como o que Maffesoli denomina de "cimento social", responsável por estabelecer vínculos. Desde a segunda metade do século 20, alguns movimentos e gêneros da canção popular - como as "tribos" planetárias que se formaram em torno do heavy metal ou do punk - são exemplares disso, do sentimento de pertencimento a um grupo como fundamento da vida social que caracteriza a metáfora de neotribalismo desenvolvida por Maffesoli.

Nesse contexto de neotribalismo, Rita Lee, assim como os demais compositores das canções midiáticas, é ao mesmo tempo um espectador e um ator, com diversos papeis, inserido na atmosfera das "tribos", sintonizado com o espírito coletivo e lidando com arquétipos enraizados na existência social.

Muitas das tribos urbanas pelas quais a compositora transitou (tropicalista, hippie, roqueira) se constituíram em torno de subgêneros do rock e do pop e se consolidaram como comunidades emocionais, cujos integrantes compartilharam os imaginários que emergiram das canções e estabeleceram processos de identificação cultural locais e internacionais em torno desses imaginários. Segundo Maffesoli (2010), o sentir 
em comum (aura estética), a experiência ética (laço coletivo) e o costume (vida cotidiana) são os elementos que constroem o sentimento de pertencimento do indivíduo nas comunidades que se formam.

Assim, as formas de geração e disseminação de elementos simbólicos quando aplicados a contextos de neotribalização, nos quais a canção popular esteja no epicentro do fenômeno, apontam para o imaginário como um vetor de processos de compartilhamento de elementos simbólicos e de identificação cultural entre os integrantes das "tribos urbanas", tanto na etapa de fruição como na de criação das canções. Nesse sentido, as composições de Rita Lee podem ter contribuído na criação e reprodução de um imaginário do amor romântico coletivo e compartilhado, principalmente em função do sucesso que alcançaram.

\section{Mapeando o imaginário romântico nas canções de Rita Lee}

Para elaborar um dos retratos possíveis sobre o imaginário do amor romântico que emerge da obra de Rita Lee, são analisadas cinco canções da compositora: "Ando Meio Desligado", "Menino Bonito", "Agora Só Falta Você", "Doce Vampiro" e "Mania de Você", que foram compostas e tornaram-se sucessos entre o final dos anos 1960 e o final da década 1970.

O processo de análise utilizado neste estudo entende a canção como um signo complexo, formada por vários signos presentes não só nas letras como também nas sonoridades. São eles os elementos responsáveis por construir os sentidos e compor o imaginário. Para identificar o universo de signos que compõe a canção, a análise busca identificar o que Roland Barthes definiu como "pontos de partida" de sentidos. Barthes entende que todo texto ${ }^{4}$ contém pontos de partida que constituem "avenidas de sentido" que, no subjetivo processo de interpretação do texto pelos interlocutores, os conduzem a outros textos (BARTHES, 2001, p. 287).

\footnotetext{
4 Barthes chama de "texto" não só o texto literário mas também outras formas de linguagem produtoras de sentidos, como a música, o filme, a fotografia, a pintura etc. 
$\mathrm{Na}$ análise textual proposta por Barthes, uma "avenida de sentido" sustenta-se no isotopismo de seus índices que a direcionam a desembocar em determinadas conotações. Nos versos que compõem a letra de uma canção, entendemos esses índices como os elementos simbólicos que emergem dessas avenidas de sentido e as sustentam. Elementos que podem expressar sentimentos, como o "ciúme", a "paixão" ou a "raiva", objetos do mundo natural com os seus simbolismos, como a "Lua", o "Sol" ou a "noite", ações, como o "esperar", o "encontrar" ou o "fugir", ou fatos sociais e comportamentais, como a "festa", a "catástrofe" ou a "fofoca", entre outros. Elementos que, mesmo quando têm o potencial de múltiplas conotações - a "noite", por exemplo, pode remeter em termos de amor romântico à solidão, à festa ou ao sexo -, assumem uma significação específica na avenida de sentido em que estão e, ao assumirem determinada significação, convergem para um dos regimes de imagem descritos por Durand.

Cada avenida de sentido é aberta e sustentada a partir de elementos simbólicos que produzem a reiteração e recorrência de uma mesma característica semântica. Esse fenômeno de coerência semântica foi definido por A. J. Greimas como isotopia, "um complexo de categorias semânticas múltiplas que possibilitam a leitura uniforme de uma história" (apud FIORIN, 2002, p. 81).

A análise aqui desenvolvida não pretende esgotar os sentidos construídos por uma canção, mas apontar, a partir de uma interpretação sustentada (isotópica) de alguns de seus sentidos possíveis, como os elementos simbólicos presentes nela compõem, criam e compartilham um determinado imaginário. A semiose desses elementos se faz, assim, não isoladamente mas em um "pacote" de significações que a canção estabelece, incluindo a influência que a sonoridade exerce sobre o(s) sentido(s) construídos. Vejamos como: 


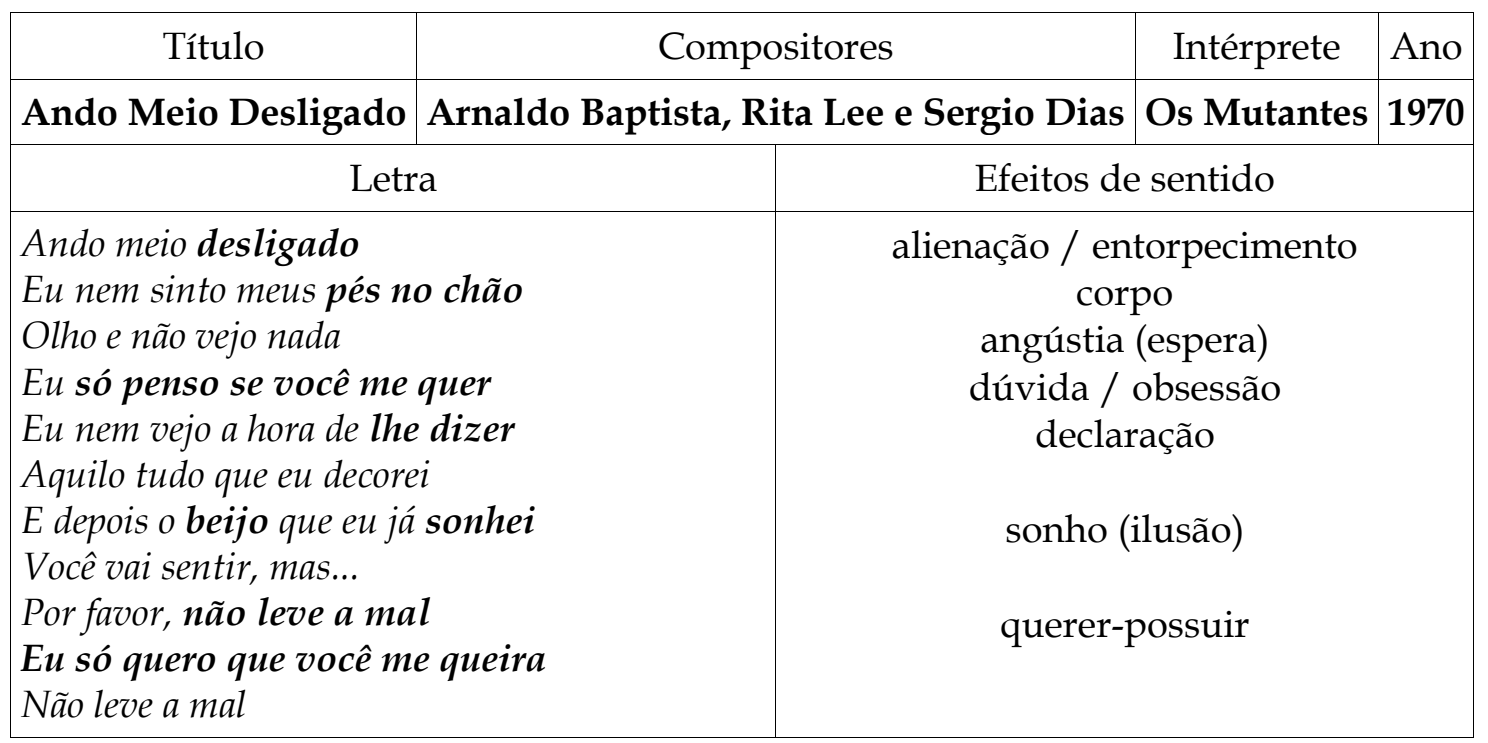

Em "Ando Meio Desligado" 5 (1970), canção representativa do Tropicalismo, com influências da estética do rock psicodélico, o protagonista (aquele que canta) revela os efeitos corporais e mentais provocados pela sensação angustiante causada pelo desejo ou necessidade em se declarar à pessoa amada (para quem ele canta). A proposta do rock psicodélico, muito presente na cultura a partir da segunda metade da década de 1960, era explorar nas letras e na musicalidade as experiências relacionadas às drogas psicoativas (SHUKER, 1999, p. 244). Nessa direção, em “Ando Meio Desligado", o protagonista declara sentir um amor que é causa do seu entorpecimento e da sua alienação. O contraste entre a batida acelerada e a cadência da voz, que remete a um canto de sedução, enfatizam esse efeito de entorpecimento causado pelo amor.

\footnotetext{
5 "Ando Meio Desligado" foi apresentada no IV Festival Internacional da Canção, em 1969, dois anos após a passeata "contra as guitarras elétricas e a influência da música norte-americana", em julho de 1967, liderada por artistas da MPB como a Geraldo Vandré, Edu Lobo e Elis Regina, e ironicamente o futuro tropicalista Gilberto Gil. Na canção, segundo Carlos Calado (2012, p. 197), "a sensação de desligamento provocada pela maconha serviu de ponto de partida".
} 


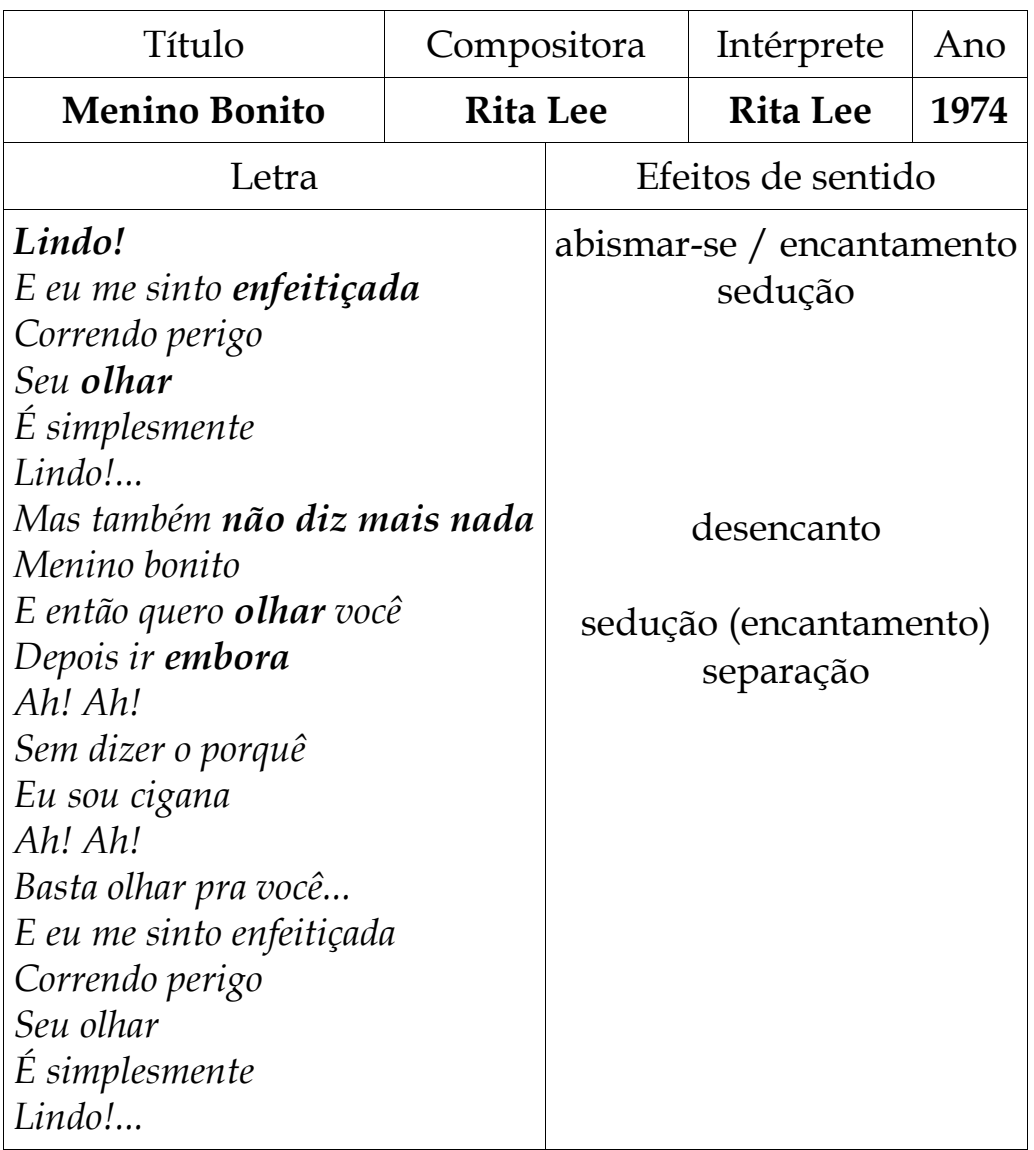

"Menino Bonito" (1974) traz a sedução como tema central. A sonoridade da canção corrobora para esse sentido ao criar uma atmosfera calma que estabelece um tom melancólico para a trajetória da protagonista, que vai do encantamento pela beleza física do sujeito para quem ela canta ao desencanto pela superficialidade dessa beleza ou pela não retribuição amorosa esperada por ela (ambas as interpretações decorrentes dos versos: Seu olhar /É simplesmente /Lindo!.../Mas também não diz mais nada.) Há na construção da letra um jogo entre a atração pelo erotismo e o desejo (frustrado) pelo romance, centrado no duplo sentido empregado para a palavra "olhar", que se refere ora à ação da protagonista de admirar o sujeito amoroso - E então quero olhar você -, ora a ser "espelho" do estado de espírito da pessoa amada - Seu olhar / É simplesmente / Lindo!. Ser seduzida pela beleza física da pessoa amada é interpretada pela protagonista como algo "perigoso" (Lindo! /E eu me sinto enfeitiçada / Correndo perigo), o que a leva a afirmar seu nomadismo amoroso: (Depois ir embora / Ah! Ah! Sem dizer o 
porquê / Eu sou cigana). "Nomadismo amoroso" (que associado ao perigo que a protagonista vê ao se sentir enfeitiçada pelo sujeito amoroso) pode remeter a uma atitude de fuga da protagonista em relação ao "amor", ao "apaixonar-se".

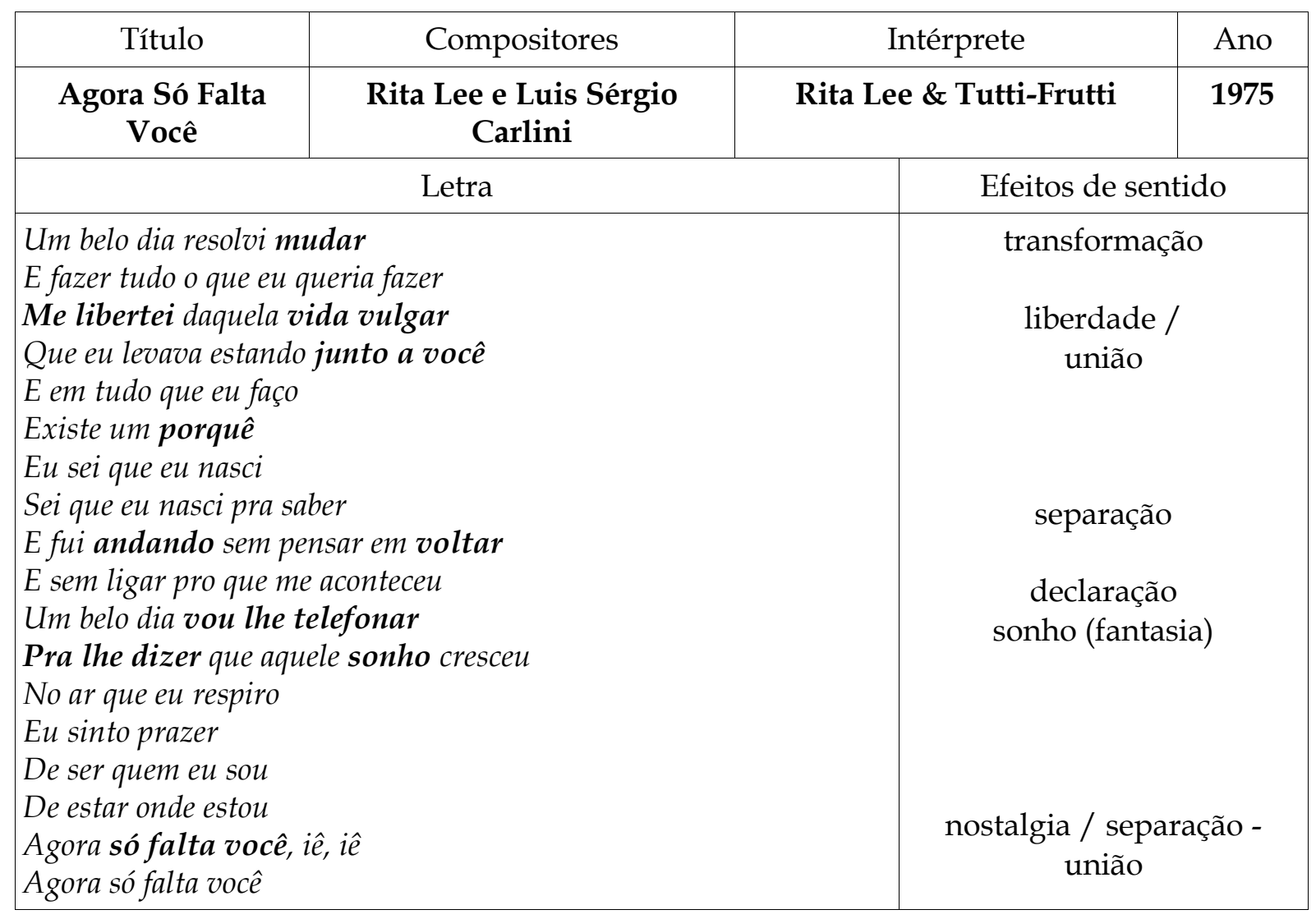

Se interpretada como uma canção sobre um relacionamento amoroso, “Agora Só Falta Você" (1975) traz uma protagonista cantando sobre o processo de libertação dela em relação à pessoa amada. A canção retrata a trajetória da situação de união entre os sujeitos amorosos até a separação, por desejo da protagonista, que ainda tem a ilusão (sonho) de retornar à situação de união, provocada pelo sentimento de nostalgia. A vida amorosa levada junto à pessoa amada é vista pela protagonista como "vulgar", que pode ter tanto o sentido de trivial, banal, como também de promíscuo, obsceno e imoral. A narrativa mostra uma percepção da protagonista de que essa transformação só estará completa quando ela voltar a unir-se com a pessoa amada (Um belo dia vou the telefonar / Pra the dizer que aquele sonho cresceu (...) / Agora só falta você, iê, iê) ou de que a pessoa amada também faça as mudanças, as transformações necessárias em sua vida. A acelerada e pesada sonoridade, associada ao hard rock que ocuparia 
parte da cena internacional e brasileira do pop-rock na primeira metade dos anos 1970, cria uma atmosfera levemente agressiva para a canção reforçando o sentido do discurso da protagonista.

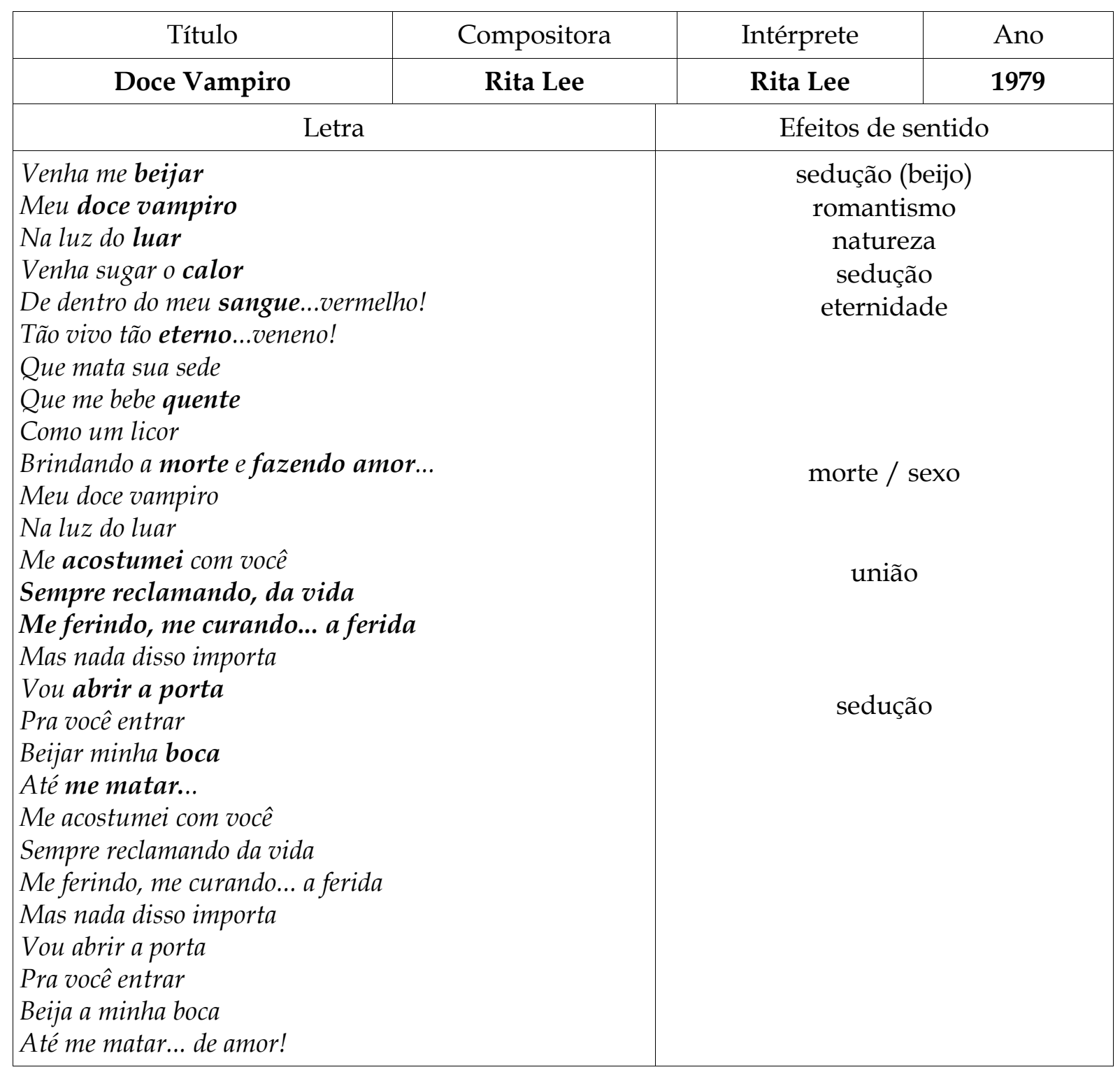

Em “Doce Vampiro” (1979), a sensualidade é o tema central a partir da referência a vários elementos simbólicos que marcaram um dos pontos altos da literatura romântica (em geral, baseado no personagem de Drácula, de Bram Stocker). Rita Lee a escreveu enquanto cumpria sentença de um ano de prisão domiciliar em São Paulo (condenada por posse e uso de drogas), inspirada pelos momentos de espera pela visita do marido Roberto Carvalho que, na época, trabalhava no Rio de Janeiro. A pro- 
tagonista recorre à metáfora do vampiro romântico para comparar o tipo de relacionamento que mantém com a pessoa amada. A carga de erotismo e sedução é construída ao longo da canção com várias metáforas: Vou abrir a porta / Pra você entrar; Que me bebe quente / Como um licor / Brindando a morte e fazendo amor. $\mathrm{O}$ "doce vampiro" por quem a protagonista está incondicionalmente seduzida e apaixonada é humanizado a partir da descrição de seus defeitos banais: Me acostumei com você / Sempre reclamando, da vida / Me ferindo, me curando... a ferida / Mas nada disso importa. A imagem da morte é associada a do sexo como ponto alto do erotismo (Vou abrir a porta / Pra você entrar / Beijar minha boca / Até me matar...) no relacionamento entre a protagonista e a pessoa amada. A sonoridade calma, com andamento lento em tom de balada, reforça a atmosfera de sedução construída pelas letras.

\begin{tabular}{|c|c|c|c|}
\hline Título & Compositora & Intérprete & Ano \\
\hline Mania de Você & $\begin{array}{c}\text { Rita Lee e Roberto } \\
\text { de Carvalho }\end{array}$ & Rita Lee & 1979 \\
\hline Letra & & Efeitos de sentido & \\
\hline $\begin{array}{l}\text { Meu bem você me dá } \\
\text { Água na boca } \\
\text { Vestindo fantasias } \\
\text { Tirando a roupa } \\
\text { Molhada de suor } \\
\text { De tanto a gente se beijar } \\
\text { De tanto imaginar } \\
\text { Imaginar! } \\
\text { Loucuras... } \\
\text { A gente faz amor } \\
\text { Por telepatia } \\
\text { No chão, no mar, na lua } \\
\text { Na melodia } \\
\text { Mania de você } \\
\text { De tanto a gente se beijar } \\
\text { De tanto imaginar } \\
\text { Imaginar! } \\
\text { Loucuras... } \\
\text { Nada melhor } \\
\text { Do que não fazer nada } \\
\text { Só prá deitar } \\
\text { E rolar com você... }\end{array}$ & & $\begin{array}{c}\text { corpo } \\
\text { sedução (fantasia) } \\
\text { sedução (beijo) } \\
\text { sedução (fantasia) } \\
\text { sexo } \\
\text { natureza } \\
\text { canção } \\
\text { obsessão }\end{array}$ & \\
\hline
\end{tabular}

O tema central de "Mania de Você" (1979) também é a sedução, acrescida de um erotismo mais explícito. A protagonista enfatiza a questão da fantasia sexual no ANAZ, Sílvio A. L. A erotização do imaginário do pop-rock brasileiro nas canções de Rita Lee. Música Popular em Revista, Campinas, ano 3, v. 1, p. 80-100, jul.-dez. 2014. 
relacionamento com a pessoa amada. O relacionamento sexual é visto como uma mania, uma obsessão, e assume uma dimensão preponderante na relação amorosa, sendo que elementos do mundo natural, como o mar e a lua, ajudam também a enfatizar a sua importância. A atmosfera de erotismo é construída não só pelos versos que o explicitam, mas também pelo tom da voz, pelas simulações de gritos e gemidos e pela ênfase dada no cantar a certos elementos simbólicos como a loucura e o ato sexual (rolar, fazer amor). Enfatizando o tema central, a sonoridade cria uma atmosfera calma e sedutora, que surge principalmente em função do ritmo e da linha melódica.

O mapeamento dos elementos simbólicos nas composições de Rita Lee (figura 2) revela algumas das mais frequentes imagens às quais ela recorre para construir sua visão sobre o amor romântico.

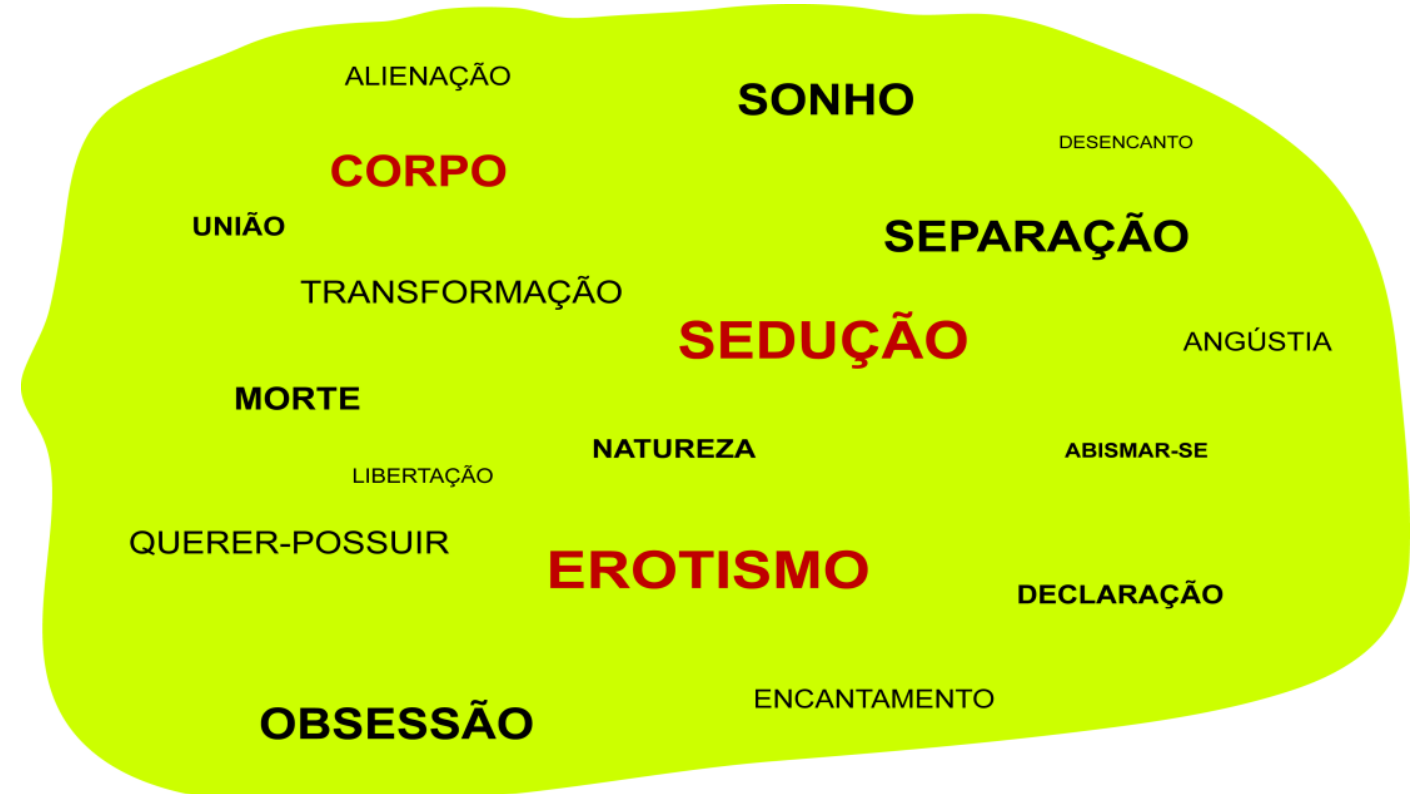

Figura 2: Elementos simbólicos do imaginário romântico nas canções de Rita Lee

Nesse retrato do imaginário do amor romântico na obra da compositora, os elementos simbólicos que remetem às imagens da sedução e do erotismo têm uma presença acentuada.

\section{A erotização do amor romântico nas canções de Rita Lee}

A erotização do imaginário do amor romântico nas canções de Rita Lee vem principalmente do predomínio das imagens da "sedução", "erotismo", "corpo", ANAZ, Sílvio A. L. A erotização do imaginário do pop-rock brasileiro nas canções de Rita Lee. Música Popular em Revista, Campinas, ano 3, v. 1, p. 80-100, jul.-dez. 2014. 
“obsessão" e "querer-possuir". São imagens que revelam: os desejos e sensações eróticas dos sujeitos amorosos, como o de ser beijado e ter relações sexuais em cenários "românticos"; a capacidade da pessoa amada de enfeitiçar e encantar apenas com a sua presença física (o abismar-se em relação à beleza de um que enfeitiça o outro); as sensações eróticas dos sujeitos amorosos e a obsessão de um em relação ao outro. São significados que remetem predominantemente às estruturas místicas e sintéticas do Regime Noturno, à medida que lidam com os arquétipos do íntimo, quente, escondido e feminino, como resultado dos movimentos de mergulhar e penetrar no mais íntimo, de amadurecer e da expressão de um realismo sensorial e da dialética dos sujeitos amorosos (antagonistas).

As canções de Rita Lee carregam para a bacia semântica do imaginário do amor romântico do pop-rock brasileiro - na qual havia uma marcante presença das estruturas heroicas do Regime Diurno, em função da imagem e do mito do herói masculino materializado na figura do "playboy", construída principalmente pelas canções de Erasmo e Roberto Carlos na Jovem Guarda - as imagens noturnas arquetípicas do feminino e do erótico.

O arquétipo feminino e a erotização do desejo da mulher em suas canções trazem para esse imaginário rastros do mito de Afrodite, a deusa grega que nas relações amorosas, conforme descreve Plutarco na obra Eróticos (2009), presidiria o carnal, as sensações, o prazer e a união dos sexos (enquanto caberia a Eros presidir o puro, os sentimentos, o espiritual e a felicidade). Em relação a essa remissão ao mito, é preciso ressaltar que, para Durand (1996), a presença de imagens arquetípicas e narrativas mitológicas nos produtos midiáticos pode resultar ou ser o resultado do desgaste e distorção desses mitos e arquétipos, com a ênfase em alguns de seus aspectos em detrimento de outros. Além de remeter a Afrodite, o poder da sedução, o erotismo e o ato sexual nas canções de Rita Lee remetem também a narrativas e arquétipos da sexualidade relacionados ao "pecado original" da mitologia judaico-cristã

\footnotetext{
${ }^{6}$ Essas remissões, assim como a presença de elementos simbólicos que remetem à imagem arquetípica da "virtude" e do mito de Dionísio, podem ser pontos de partida para uma discussão - que não é o foco desta investigação - sobre o quanto o imaginário do amor romântico que emerge das canções de Rita Lee traz uma visão conservadora ou libertária sobre o tema. 
No pop-rock internacional no período, o tema da sexualidade também tornou-se cada vez mais presente nas canções. Das mais ingênuas, como "I Want to Hold Your Hand" (1964), dos Beatles, ou "I'm a Believer" (1966), dos Monkees, às mais provocativas, como "Light My Fire” (1967), do The Doors, “Tonight's the Night (Gonna Be Alright)" (1976), de Rod Stewart, “Night Fever” (1978), dos Bee Gees, ou “My Shrona” (1979), do The Knack, elementos simbólicos como “sedução”, “sexo”, " quererpossuir" e "corpo" tornaram-se mais frequentes e conduziram também a uma erotização do imaginário do amor romântico (ANAZ, 2013, pp. 121-122).

No ápice do sucesso nacional de Rita Lee, a erotização na canção conduzida por uma figura feminina no pop-rock internacional aparece em "Physical", que na interpretação de Olivia Newton-John chega ao primeiro lugar da Billboard em 1981. Em "Physical", a protagonista revela ao seu objeto de desejo que já cumpriu todas as etapas da sedução e que é hora deles fazerem sexo. Ela enfatiza, sem realizar nenhuma declaração de amor, um sentimento de desejo bruto (You gotta know that you're bringin' out the animal in me) que transforma a pessoa amada em um objeto sexual. Essa narrativa da sexualidade e do poder de sedução da mulher, a partir do ponto de vista feminino, se consolidaria nos anos seguintes com o sucesso de canções como "Like a Virgin", de Madonna (ibidem).

Na obra de Rita Lee, a erotização do imaginário do amor romântico parece acompanhar a visão que algumas tribos urbanas, das quais ela compartilhava o imaginário, desenvolviam sobre a relação com a sexualidade, principalmente a partir final da segunda metade dos anos 1960, quando a chamada "revolução sexual" ocupou os imaginários dos jovens.

A ênfase na sexualidade mais explícita em suas canções aproxima sua visão do amor romântico da perspectiva da "dupla chama” de Octávio Paz, em que o fogo, símbolo da sexualidade humana, é composto pela chama vermelha que remete ao erotismo, enquanto a azul remete ao amor, sendo este a "metáfora final da sexualidade", uma purificação que "transforma o sujeito e o objeto de encontro erótico em pessoas únicas" (PAZ, 1994). 


\section{Considerações finais}

Os diálogos que Rita Lee estabeleceu com os sistemas socioculturais em que esteve inserida parecem ter exercido um papel decisivo nas escolhas estéticas e na construção do imaginário do amor romântico nas canções aqui analisadas. A sonoridade é o resultado de um processo de hibridização entre elementos do rock angloamericano e de gêneros brasileiros e as letras apresentam elementos simbólicos que enfatizam um protagonismo feminino, com pretensões libertárias e altamente sexualizado.

Pensando as composições de Rita Lee a partir da ideia de neotribalismo proposta por Maffesoli, na qual o imaginário opera como um cimento social nos processos de adesão à ética, estética e costumes de determinada tribo urbana, há indicadores, tanto na sonoridade quanto nas letras de suas canções, do compartilhamento ${ }^{7}$ pela compositora do imaginário de parte do pop-rock dos anos 1960 e 1970.

A erotização do amor romântico em suas canções surge, nesse sentido, como índice de irreverência e de um espírito desafiador em relação às instituições e aos valores morais dominantes. É preciso ressaltar que essa erotização, no entanto, se dá em um processo de aceitação e assimilação das "ousadias" e "profanações" que caracterizam a lógica da canção midiática, no contexto social e econômico em que se inserem as lógicas da indústria fonográfica e dos meios de comunicação de massa.

Ainda assim, a erotização que emerge de suas canções traz como contribuição para o imaginário do pop-rock brasileiro colocar em evidência a imagem arquetípica feminina e elevar a questão da sexualidade e do erotismo a partir do ponto de vista da mulher para o primeiro plano. Além disso, o predomínio do imaginário noturno em suas canções, com movimentos de mergulho no mais íntimo e de amadurecimento, contrapôs-se ao do imaginário diurno da Jovem Guarda, de estruturas heroicas e movimentos beligerantes.

\footnotetext{
${ }^{7}$ Compartilhamento no sentido de contribuir para tal imaginário coletivo ("tribal”), assim como aderir a esse mesmo imaginário e reproduzir elementos dele. 
O mapeamento do imaginário apontou também rastros do mito de Afrodite, assim como de elementos que remetem aos arquétipos do "pecado" e da "virtude", assim como ao mito de Dionísio. Essas pistas sinalizam a possibilidade, em futuros estudos, da realização de uma mitoanálise (Durand) da obra de Rita Lee, o que possibilitaria identificar os arquétipos e mitos que alimentaram suas criações.

Entendemos que os resultados apresentados nesta investigação mostram a viabilidade metodológica de se aplicar a articulação dos conceitos de mediação cultural, neotribalização e imaginário, além do recurso à análise da semiose das letras e músicas, para se estudar como ocorre a construção e o compartilhamento de imaginários pela canção midiática. Nesse sentido, parecem eficientes os mapeamentos dos diálogos culturais estabelecidos pelo compositor da canção e dos principais elementos simbólicos presentes nas letras e músicas, com a reflexão sobre os significados que eles potencialmente trazem.

\section{Referências}

ANAZ, Sílvio A. L. A comunicação do amor romântico no pop-rock brasileiro. 280 f. Tese (Doutorado em Comunicação e Semiótica) - Pontifícia Universidade Católica de São Paulo, São Paulo, 2013.

BARTSCH, Henrique. Rita Lee mora ao lado. São Paulo: Panda Book, 2006

BARTHES, Roland. A aventura semiológica. São Paulo: Martins Fontes, 2001.

Fragmentos de um discurso amoroso. São Paulo: Martins Fontes, 2003.

CALADO, Carlos. A Divina Comédia dos Mutantes. São Paulo: Editora 34, 1995.

COSTA, Jurandir Freire. Sem fraude nem favor: estudo sobre o amor romântico. Rio de Janeiro: Rocco, 1998.

CANCLINI, Néstor. Culturas Híbridas: estratégias para entrar e sair da modernidade. São Paulo: Edusp, 1997.

DURAND, Gilbert. A Imaginação Simbólica. São Paulo: Editora Cultrix, 1988. . Campos do Imaginário. Lisboa: Instituto Piaget, 1996. 
As Estruturas Antropológicas do Imaginário. São Paulo: Martins Fontes, 2002.

FIORIN, José Luiz. As astúcias da enunciação. São Paulo: Editora Ática, 2. ed., 2002.

LEE, Rita. Entrevista: Rita Lee finaliza disco e recebe homenagens. Folha de S. Paulo, São Paulo, 29 abr. 1997.

Entrevista: Semi-reclusa, Rita Lee quer fazer disco new age. Folha de S. Paulo, São Paulo, 17 jul. 2000.

Entrevista: “Não nasci para casar e lavar cuecas", revela Rita Lee. Rolling Stone, São Paulo, edição 15, dez. 2007.

Entrevista: Rita Lee faz pic-nic com velhos hits em nova turnê. O Estado de $S$. Paulo, São Paulo, 3 abr. 2008.

LEVITIN, Daniel J. The World in Six Songs: how the musical brain created the human nature. Nova York: Dutton, 2008.

MAFFESOLI, Michel. O Tempo das Tribos. Rio de Janeiro: Forense Universitária, 2010.

. O imaginário é uma realidade. Entrevista a Juremir Machado da Silva. In Revista FAMECOS, n. 15, agosto de 2001.

MARTIN-BARBERO, Jesús. Dos Meios às Mediações: comunicação, cultura e hegemonia. Rio de Janeiro: Editora UFRJ, 6.a ed., 2009.

PAZ, Octávio. A dupla chama: amor e erotismo. São Paulo: Siciliano, 1994.

PLUTARCO. Obras Morais - Diálogo sobre o Amor - Relatos de Amor. Coimbra: Universidade de Coimbra, 2009.

SHUKER, Roy. Vocabulário de música pop. São Paulo: Hedra, 1999.

WHITBURN, Joel. Billboard Top 1000 Singles 1955-2000. Milwakee: Hal Leonard, 2001. 